Сергій Богунов

кандидат технічних наук, ORCID ID 0000-0002-4946-1604

Ольга Черних, Національний університет оборони України імені Івана Черняхівського ORCID ID 0000-0001-9865-5598

Юрій Черних, кандидат технічних наук, доцент, Військовий інститут Київського національного університету імені Тараса Шевченка ORCID ID 0000-0002-0780-6627

\title{
ОРГАНІЗАЦІЯ ПЦДГОТОВКИ ОФІЦЕРІВ ДЛЯ ЗБРОЙНИХ СИЛ РЕСПУБЛІКИ ЛИТВА
}

У статті розглянуто досвід підготовки офічерів для збройних сил республіки Литва. Проаналізовано модель побудови кар'єри офічера, починаючи з присвоєння первинного офічерського звання до присвоєння військового звання вищого офічерського складу. Наведено відомості шзодо існуючої мережі військових навчальних закладів для підготовки офіиерів тактичної, оперативної та стратегічної ланок військового управління сухопутних військ, військово-повітряних сил та військово-морських сил. Приведено вимоги для вступників до військових навчальних закладів різних ступенів підготовки. Означені варіанти організації підготовки офіцерів на первинні посади призначення. Проведено аналіз змісту підготовки офіцерських кадрів для різних видів збройних сил та певних рівнів військового управління.

Ключеві слова: система військової освіти; збройні сили Литви; мережа військових навчальних закладів; досвід підготовки офіцерів.

Постановка проблеми. Проводячи дослідження закордонного досвіду будівництва та реформування збройних сил інших країн, у тому числі їхньої складової - системи військової освіти, бачимо, що в кожній країні він має специфічне національне підгрунтя. Тому зрозуміло - не треба сліпо копіювати будь яку систему підготовки офіцерських кадрів, що існує у збройних силах (ЗС) США, або Франції, або Великобританії, які мають вікові традиції з навчання військових фахівців. Водночас у військовій педагогічній практиці різних країн світу існують загальні методичні підходи, які доцільно враховувати i використовувати. На наш погляд, цікаво дослідити шлях сучасної трансформації систем військової освіти (СВО) збройних сил країн, що входили до складу колишньої організації Варшавського договору, зокрема у збройних силах республіки Литви (РЛ), як складової СВО колишнього Радянського Союзу.

У статті наведено аналіз досвіду підготовки офіцерів у збройних силах РЛ, що виконаний під час проведення дослідження у рамках науководослідної роботи «Рекомендації щодо подальшого реформування системи військової освіти Збройних Сил України на основі вивчення досвіду трансформації систем військової освіти у країнах - колишніх членів організації Варшавського договору до сучасних моделей підготовки 
військових фахівців, прийнятих у країнах - членах НАТО» (шифр Підготовка-Т).

Аналіз досліджень і публікацій. Дослідженню питань, що пов'язані 3 аналізом систем підготовки військових фахівців інших країн, присвячено низку наукових праць вітчизняних науковців. Зокрема, підготовку офіцерських кадрів у США досліджено у працях С. Владимирова, Н. Дрожина, В. Іващенка, П. Лебедя, В. Кружиліна, К. Колчіна, Р. Равлика, В. Ожгихіна, О. Панова, І. Попова, А. Стрелецького; у Франції - в працях В. Владимирського, В. Захарова, О. Мітіна, О. Коп’ьєва, М. Сімакова, П. Колесова; у Німеччині - в працях К. Колчіна, В. Лазукина, Ю. Федосєєва, В. Чернова; у Великобританії - в працях В. Бровкина; порівняльний аналіз систем підготовки військових фахівців у зарубіжних збройних силах здійснено у наукових дослідженнях О. Барабанщикова, М. Гацька, М. Нещадима, Б. Олексеєнка, Ю. Приходька, В. Телеліма, С. Печерова, О. Челпанова, В. Ягупова. Разом $з$ тим, слід зазначити, що незважаючи на різноманітність публікацій щодо систем військової освіти в інших країнах, у першу чергу, провідних країн-членів НАТО, дослідження сучасного стану підготовки офіцерських кадрів у ЗС РЛ наражаються на такі проблеми: неповнота та недостатня аналітичність джерельної бази; нехтування необхідністю грунтовного вивчення досвіду підготовки військових фахівців у невеликих країних, що мають малочисельні ЗС тощо.

Метою статті $\epsilon$ проведення аналізу сучасного стану СВО республіки Литва для врахування досвіду з підготовки офіцерських кадрів під час подальшої реформи національної системи військової освіти.

Методи досліджень. Для розв'язання поставлених дослідницьких завдань використана система загальнонаукових i спеціальних методів теоретичного та емпіричного дослідження, а саме теоретико-методологічний аналіз проблеми, аналіз наукової літератури 3 проблеми дослідження, систематизація та узагальнення наукової інформації, що стосується сутності й змісту визначених завдань, моніторинг існуючій системи підготовки військових фахівців у ЗС РЛ, наукове узагальнення, загальнонаукові методи логічного та порівняльного аналізу, системного підходу, експертна оцінка, аналіз та інтерпретація отриманих теоретичних та емпіричних даних.

Виклад основного матеріалу. Протягом всієї своєї історії у СВО РЛ відбувалися постійні зміни, які були зроблені за моделями різних країн, що враховували існуючи ресурси, політику влади, політику міжнародного співробітництва тощо. В даний час СВО та система підготовки збройних сил Литви заснована на тренувальній моделі ЗС США. При цьому провідне місце у СВО належить системі підготовки офіцерських кадрів. Загальна модель організації підготовки військових фахівців нами розглянута у роботі [1]. Зокрема у статті визначена модель системи підготовки литовських офіцерів, що приведена на рис. 1. 


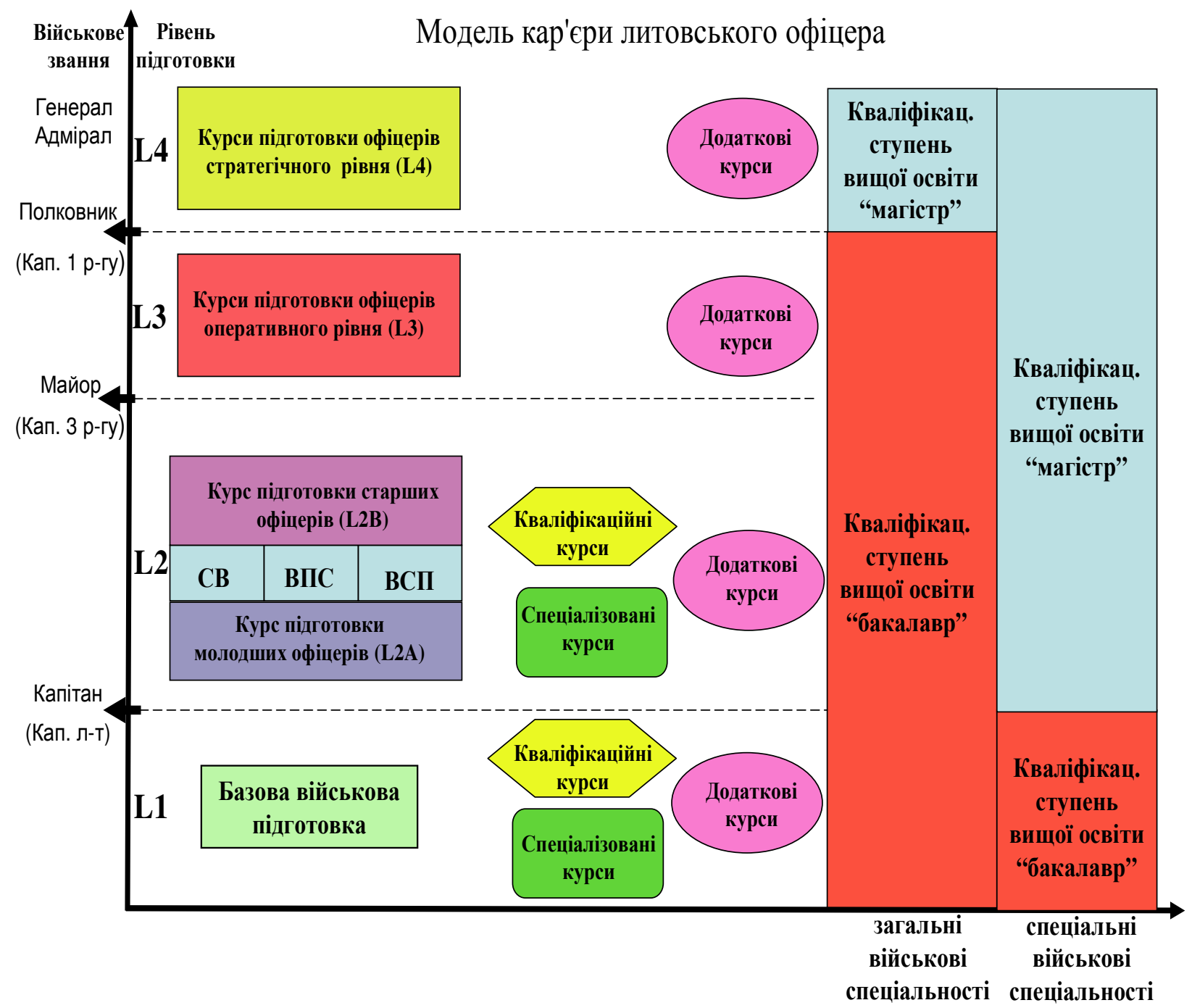

Рис. 1 - Модель системи підготовки литовських офіцерів

Правовою основою організації підготовки офіцерських кадрів $\epsilon$ Конституція Литовської Республіки [2], закони Литовської Республіки «Про науку та дослідження» [3], «Про організацію системи національної оборони Литовської Республіки і про військову службу» [4], постанова уряду Литви «Про затвердження статуту військової академії» [5], накази міністра освіти i науки [6, 7], накази міністра оборони [8 - 10] та інші нормативно-правові акти.

Підготовка осіб на посади офіцерського складу здійснюється на основі повної загальної середньої, професійної (професійно-технічної) чи вищої освіти, для здобуття відповідних ступенів вищої освіти та рівнів військової освіти (тактичний, оперативний або стратегічний).

Периий (базовий) рівень підготовки офіцера (L1). Ціль навчання на цьому рівні полягає в тому, щоб розвинути лідерські навички і надати майбутнім офіцерам знання і навички, необхідні для командування взводом сухопутних військ (ВПС, сил спеціальних операцій) або для виконання інших рівних посадових обов'язків. Офіцери, які завершили навчання на цьому рівні, повинні бути спроможними керувати взводом, організовувати i 
проводити тренування та інші заняття з підлеглим особовим складом, знати можливості взводу, роти, а також інших рівних підрозділів ВПС і сил спеціальних операцій, щоб розуміти основи тактики, бойової підтримки та ведення бойових дій. Офіцери, які отримали базову військову підготовку, можуть бути спрямовані на курси підвищення кваліфікації та інші курси в залежності від потреб литовських збройних сил для комплектування відповідних посад.

Прийом до військового навчального закладу здійснюється в три етапи:

Перший етап - це професійний тест на профпридатність. Цей тест визначає і оцінює придатність окремих осіб для проходження військової служби. Оцінюються особисті якості майбутніх офіцерів, пізнавальні здібності, загальна освіта, вміння вирішувати проблеми та їх фізична форма. Кандидати в офіцери литовських ВПС повинні пройти додатковий тест на профпридатність відповідно до вимог Авіаційного інституту Вільнюського технічного університету імені Гедімінаса (АIBTУ).

Другий етап - медичне обстеження в комісії військової медичної служби 3 військово-медичного огляду. Кандидати в офіцери ВПС проходять додаткове медичне обстеження відповідно до вимог АІВТУ.

Третій етап - подача заявки на навчання до Литовської військової академії (ЛВА). Заяви обробляються тільки після того, як кандидати завершили перші два етапи. Залежно від зібраних балів складається рейтинг кандидатів на навчання.

В ході подальшого навчання продовжується вивчення найважливіших якостей та здібностей майбутніх командирів і відбір триває: курсанти, в залежності від академічної заборгованості, особистих якостей, професійних схильностей або інших важливих причин, пов'язаних 3 проходженням військової служби, можуть бути відрахованими від проходження навчання;

Випускникам ЛВА присвоюється первинне офіцерське звання i, з огляду на потреби литовських збройних сил і успішності підчас навчання, офіцери укладають професійні контракти та приймаються на кадрову військову службу.

Базова підготовка офіцерів сухопутних військ. Майбутні офіцери проходять підготовку в галузі військової освіти в поєднанні 3 послідовними університетськими навчальними програмами (у галузях: управління оборонними технологіями, міжнародних відносин, національної безпеки i оборони). Навчання у ЛВА складається 3 двох навчальних програм: базової програми підготовки офіцерів та програми університетського навчання. Залежно від майбутньої посади офіцери, при необхідності, проходять також відповідні курси спеціалізації. Серед вступників 2018 року (57 чоловіків та 7 жінок) 19 осіб вступили на навчання за програмою «Національна безпека i оборона», 27 осіб за програмою «Міжнародні відносини» та 18 осіб за програмою «Управління сучасними оборонними технологіями» [11].

Для того, щоб отримати базову військову підготовку, всі курсанти першого курсу ЛВА спочатку направляються на первинну (початкову) військову підготовку, яка проходить в рамках базової військової програми 
навчання. 3 метою поліпшення початкової військової підготовки на цьому етапі курсанти направляються на різні практики та стажування до військових частин. Військова підготовка здійснюється відповідно до навчальної програми, затвердженої командувачем литовськими ЗС, підготовленої відповідно до кваліфікаційних вимог, затверджених міністром національної оборони. Ця програма включає теоретичні та практичні заняття, польові вправи i стажування у військових частинах. Військова підготовка фокусується на вишколі та розвитку лідерських якостей майбутніх офіцерів. Після проходження цієї підготовки випускники набувають відповідні командні знання і навички, на підставі яких їм присвоєно кваліфікацію офіцера-командира.

Університетське навчання проводиться відповідно до навчальних програм ЛВА, включених до Реєстру навчальних програм i навчальних планів. Випускникам військової академії видається диплом бакалавра у відповідної галузі знань. 3 метою забезпечення належної підготовки офіцерів періодично уточнюються кваліфікаційні вимоги для випускників ЛВА i відбувається коригування навчальних програм.

3 урахуванням потреб литовських ЗС, угод із зарубіжними країнами і фінансових можливостей, частина майбутніх офіцерів сухопутних військ, відібраних за конкурсом, навчаються в інших іноземних військових навчальних закладах. Офіцери, які закінчили іноземні військові навчальні заклади, що не забезпечують отримання вищої освіти, продовжують навчання у ЛВА. Так, з числа випускників 2017 року 16 осіб покращили свої знання за програмою обміну студентами «Erasmus» у ВНЗ Польщі, Болгарії, Франції, Чехії та Австрії, 2 курсанти навчалися у Військовому інституті у США, штат Вірджинія [11].

Базова підготовка офіцерів резерву. Офіцери резерву проходять підготовку на курсах підготовки командирів резерву (КПКР) з числа осіб, які мають вищу освіту. Програма навчального курсу командира резерву підготовлена відповідно до кваліфікаційних вимог, затверджених міністром національної оборони. При підготовці офіцерів, використовується комбіноване дистанційне навчання, яке включає в себе вивчення теоретичного матеріалу і навчання у ЛВА, що спрямовано на надання спеціальних військових знань та навичок. Мета цих курсів - надати особі достатні теоретичні знання і практичні навички для успішного виконання службових обов'язків в резервних підрозділах. Наприклад, ці курси призначені для підготовки військових юристів, які навчаються або закінчили литовські вищі навчальні заклади.

Базова підготовка офіцерів ВПС. Мета навчання майбутніх офіцерів ВПС полягає в розвитку лідерських якостей офіцера, підготовці для отримання достатніх теоретичних знань і практичних навичок для виконання завдань, покладених на авіаційних фахівців. Для того, щоб отримати базову військову підготовку, курсанти першого курсу ЛВА спочатку направляються на первинну (початкову) військову підготовку, яка проходить в рамках 
базової військової програми навчання. 3 метою поліпшення початкової військової підготовки на цьому етапі курсанти направляються на різні практики та стажування до військових частин.

Базова підготовка офіцерів ВПС проводиться у ЛВА та в інших вищих навчальних закладах відповідно до затверджених навчальних планів та індивідуальних програм підготовки: пілотів повітряних суден; фахівців 3 управління повітряним рухом; авіаційної механіки; автоматизації та управління (авіаційне електрообладнання, електронна техніка тощо).

Майбутні офіцери ВПС здобувають вищу освіту в певних вищих навчальних закладах, після чого їм видається диплом бакалавра у відповідній галузі знань, а військову освіту вони отримують у ЛВА. Навчальна програма для майбутніх офіцерів складена відповідно до кваліфікаційних вимог, затверджених міністром національної оборони. Військова частина навчальної програми офіцера ВПС включає теоретичні, практичні заняття, польові вправи і стажування у військових частинах.

Беручи до уваги потреби литовської армії та угоди із зарубіжними країнами, частина офіцерів ВПС навчається в іноземних військових навчальних закладах.

Базова підготовка офіџерів ВMC. Мета навчання майбутніх офіцерів ВМС полягає в розвитку лідерських якостей офіцера, підготовці для отримання достатніх теоретичних знань $\mathrm{i}$ практичних навичок для експлуатації бойової частини корабля. Для того, щоб отримати базову військову підготовку, курсанти першого курсу ЛВА спочатку направляються на первинну (початкову) військову підготовку, яка проходить в рамках базової військової програми навчання. 3 метою поліпшення початкової військової підготовки на цьому етапі курсанти направляються на різні практики та стажування до військових частин.

Базова підготовка офіцерів ВМС проводиться у ЛВА та інших вищих навчальних закладах Литви відповідно до затверджених навчальних програм для вивчення штурманської справи або правил експлуатації суднового енергетичного устаткування у відповідності до вимог, затверджених міністром національної оборони, та вимог Міжнародної конвенції про стандарти навчання, сертифікації та несення вахти для моряків. Навчальні заклади, в яких навчаються майбутні офіцери ВМС, повинні бути сертифіковані та відповідати вимогам для підготовки і кваліфікації моряків відповідно до Міжнародної конвенції про стандарти навчання, сертифікації та несення вахти для моряків.

Майбутні офіцери ВМС отримують вищу освіту в певних вищих навчальних закладах, після чого їм видається диплом бакалавра у відповідній галузі знань, а військову освіту вони отримують у ЛВА. Навчальна програма для майбутніх офіцерів складена відповідно до кваліфікаційних вимог, затверджених міністром національної оборони. Військова частина навчальної програми офіцера ВМС включає теоретичні, практичні заняття, польові вправи і стажування на кораблях. 
Базовий курс для підготовки офіцерів у ЛВА. Мета - підготовка тактично і технічно грамотних офіцерів ЗС Литви, здатних до ефективного використання здобутих знань та практичних навичок під час проходження військової службі. Загальна тривалість базового курсу офіцера складає 4 роки, у тому числі: 3,5 роки (бакалаврська підготовка у певної цивільної галузі знань + військова підготовка) + 0,5 роки - військова підготовка.

Курс ділиться на окремі періоди за навчальним роком і семестрами:

перший рік (1-й і 2-й семестри): проводиться базова (індивідуальна) військова підготовка курсанта. За перший рік курсант набуває початкову військову підготовку на рівні солдата;

другий рік (3-й і 4-й семестри): вивчення питань щодо застосування тактичних процедур управління під час ведення взводом бойових дій в оборонної та наступальної операціях;

третій рік (5-й і 6-й семестри): вивчення питань щодо застосування тактичних процедур управління під час ведення взводом бойових дій у місті; управління кризовими ситуаціями; застосування відомчих процедур управління на рівні роти в оборонних і наступальних операціях; концепція територіальної оборони і принципи роботи командира;

четвертий рік (7-й і 8-й семестри): формування загальних компетентностей відповідно до посадових обов'язків офіцера (професійна англійська мова, організація навчальних занять 3 підлеглим особовим складом, охорона навколишнього середовища тощо). В цілому курси проходять за напрямом певної військової спеціалізації (командир мотопіхотного взводу; артилерійської (гаубичної, мінометної) батареї, саперного взводу тощо)

Після успішного проходження базового курсу підготовки офіцера та завершення бакалаврської підготовки курсанту присвоюється військове звання лейтенанта і він призначається в одну з військових частин ЗС Литви. У 2017 році в ЛВА завершили підготовку 53 випускники (45 чоловіків та 8 жінок), 3 яких продовжили військову службу в сухопутних військах - 46 осіб, ВПС 4 особи та ВМС - 3 особи [12].

Другий (тактичний) рівень підготовки офіиерів (L2). Мета навчання полягає в продовженні професійного розвитку офіцера і розвитку його особистих здібностей, отриманні додаткових знань і навичок, необхідних для виконання обов'язків молодших офіцерів на відповідних посадах в штабі батальйону або підрозділі рівному військової частині, а після проходження додаткової підготовки для виконання обов'язків старших офіцерів під час планування і проведення спільних бойових дій (операцій). Офіцери, які завершили навчання на цьому рівні, повинні вміти планувати операції на батальйонному i бригадному рівнях, знати організаційну структуру військових частин, їх бойові можливості, характеристики озброєння i військової техніки, мати знання в галузі міжнародної та національної безпеки, управління проектами, керівництва, військової етики, права, бойової підготовки та військового управління. 
На другому рівні підготовки офіцери направляються на командноштабні курси молодших офіцерів (тактичний рівень), а також на спеціальні, кваліфікаційні та інші курси в залежності від потреб литовських збройних сил і можливостей кар'єрного росту офіцер.

Підготовка офріиерів сухопутних військ тактичного рівня складається 3 двох етапів: курс підготовки молодших офіцерів (L2A); курс підготовки старших офіцерів (L2B).

Метою курсів підготовки молодших офіцерів $є$ підготовка посадових осіб, здатних виконувати обов'язки молодших офіцерів у штабі батальйону або військової частини, еквівалентної йому. Курси розвивають лідерські якості, теоретичні знання i практичні навички офіцера, необхідні для професійного виконання обов'язків молодших офіцерів у штабі батальйону. Молодші офіцери проходять підготовку в ЛВА, але відповідно до потреб литовських збройних сил і фінансових можливостей, частина офіцерів, відібраних за конкурсом, також проходять підготовку в іноземних військових навчальних закладах.

Метою курсу підготовки старших офіцерів сухопутних військ $\epsilon$ підготовка старших посадових осіб штабів сухопутних військ, здатних грамотно планувати і керувати бойовими діями (одиночними операціями) i вирішувати інші завдання. Курси проводяться на базі ЛВА.

Метою курсу підготовки старших офіиерів ВПС є підготовка начальників штабів для планування і здійснення операцій на цьому рівні. Курс фокусується на аналізі, плануванні, логістики і аспектах безпеки проведення повітряних операцій, а також на питаннях в галузі політології, управління проектами та лідерства. Беручи до уваги невелику потребу в цих курсах, курси організовуються спільно з іншими зарубіжними країнами. 3 урахуванням потреб і фінансових можливостей литовських збройних сил, частина офіцерів, відібраних на основі конкурсу, навчаються в інших зарубіжних військових навчальних закладах.

Метою курсу підготовки старших офіиерів ВМС є підготовка посадових осіб для планування і керівництва ВМС на рівні операцій. Беручи до уваги невелику потребу в цих курсах, курси організовуються спільно 3 іншими зарубіжними країнами. 3 урахуванням потреб і фінансових можливостей литовських збройних сил, частина офіцерів, відібраних на основі конкурсу, навчаються в інших зарубіжних військових навчальних закладах.

Tретій (оперативний) рівень підготовки офіщерів (L3). Мета навчання $\epsilon$ підготовка командирів батальйону або відповідних їм військових підрозділів, начальника штабу бригади. Ці курси покращують командні навички офіцерів 3 керівництва підлеглими військовими частинами для забезпечення проведення спільних операцій, міжнародної безпеки, а також при плануванні оборони країни і управлінні ресурсами. Термін навчання 4-5 місяців.

Вимоги до кандидатів для навчання на курсах. До навчання залучаються офіцери з військовим званням капітана (капітан-лейтенанта), які завершили навчання у ЛВА принаймні 6 років тому та до звільнення з військової служби 
у запас яких залишилося не менше 4-х років. Офіцери повинні мати сертифікати захисту національних секретів (бажано також мати сертифікат HATO). Рівень знання англійської мови за стандартом HATO STAAG 6001 повинен оцінюватися щонайменше на рівні 2222. Перевагою у виборі кандидатів на курси є проходження військової служби на посаді командира роти, або батальйону, або офіцера штабу бригади.

На оперативному рівні курс проводиться в Балтійському військовому коледжі. Беручи до уваги потреби і фінансові можливості литовських збройних сил, частина офіцерів, відібраних за конкурсом, навчається в командно-штабних коледжах Сполученого Королівства, Данії, США, Франції, Швеції, Німеччини та інших зарубіжних країн.

Четвертий (стратегічний) рівень підготовки офіцерів (L4). Мета навчання полягає в тому, щоб підготувати офіцерів до виконання посадових обов'язків на стратегічному рівні, дати можливість удосконалювати свої знання і навички, необхідні для вирішення складних питань і складних проблем. Підготовка осіб офіцерського складу стратегічного рівня на посади, що належать до переліку загальних військових посад, здійснюється у ЛВА шляхом навчання за магістерськими програмами або на стратегічному курсі у Балтійському військовому коледжі. Для навчання на магістерському рівні приймаються офіцери, які отримали дозвіл міністра національної оборони Литви та державні службовці інших державних установ за згодою 3 міністерством національної оборони.

Курси забезпечують отримання знань в області прийняття рішень на вищому рівні, стратегії, розробці військової політики, міжнародного співробітництва, кризового управління, а також геополітичні і стратегічні знання, необхідні для виконання обов'язків вищих воєначальників.

Курси військової кар'єри стратегічного рівня проводяться в Балтійському військовому коледжі (Естонія), Коледжі оборони НАТО в Римі (Італія), військових коледжах США, Королівському британському оборонному коледжі та інших іноземних військових коледжах.

На четвертому рівні навчання офіцери відправляються на курси військового коледжу, а також на інші курси в залежності від потреб литовських збройних сил і можливостей кар'єрного росту для офіцера.

Залежно від типу курсів складаються такі каталоги офіцерських курсів:

- каталог курсів кар'єри офіцерів, затверджений міністром національної оборони;

- каталог навчальних курсів, затверджених командувачем збройними силами Литви.

Офіцери направляються на кваліфікаційні курси відповідно до вимог, встановлених в документах, що регламентують отримання та продовження відповідних ліцензій, дозволів і кваліфікаційних сертифікатів. Якщо необхідно, офіцери можуть бути відправлені на інші курси. Каталоги курсів посадових осіб уточнюються, якщо необхідно, але не рідше одного разу на рік. 
Організація навчання офіцерів. Навчання офіцерів складається 3 наступних основних етапів: визначення потреб у навчанні; планування навчання; відбір кандидатів; організація навчання; оцінка навчання.

Потреби в навчанні визначаються шляхом аналізу стратегічних цілей, розробки доктрин, завдань для ЗС Литви, розвитку оборонного потенціалу, міжнародних зобов'язань та індивідуальних планів кар'єри для офіцерів. Оцінка потреб включає до себе: підготовку персоналу, необхідного для виконання поставлених завдань, аналіз існуючого і необхідного військового персоналу, а також кваліфікаційних вимог до них; аналіз відповідності існуючого персоналу цим вимогам; кар'єрні перспективи офіцерів, штатні зміни персоналу та інші критерії та фактори .

Навчання офіцерських кадрів організується відповідно до потреб і шляхом вибору відповідних методів навчання та форм навчання (очна, дистанційна або заочна). Вибір методів і форм навчання визначає цілі навчання, очікувані результати, оцінює фінансову раціональність, кількість викладачів та інструкторів, необхідних для навчання, необхідні кошти для навчання та інфраструктуру. Залежно від цих оцінок вибирається найбільш ефективна і раціональна форма навчання і підготовки офіцерів.

Списки кандидатів для направлення на навчання складаються 3 урахуванням потреб литовських 3С та індивідуальних планів кар'єри офіцерів, наявності військової освіти, військової підготовки, досвіду, рівня володіння іноземною мовою, віку, доступу до секретної інформації.

Офіцер повинен також відповідати наступним критеріям для направлення на кар'єрні курси:

завершити кар'єрний курс нижчого рівня (за винятком відправки на курси рівня L1);

має пройти більше половини терміну, знаходження у відповідному військовому званні (за винятком відбору курсів молодших офіцерів);

повинен залишатися на військовій службі не менше трьох років до звільнення з військової служби відповідно до його військовим званням;

не мати незнятих дисциплінарних стягнень.

Військово-професійна підготовка студентів на посади молодмого офіиерського складу (резерву).

Міністерство оборони проводить підготовку (тренінги) молодших офіцерів (резерву) з числа студентів вищих навчальних закладів та щороку пропонує ним подати заявки на участь у відборі на ці тренінги. Відібрані кандидати проходять військову підготовку, починаючи 31 вересня, у м. Вільнюс, м. Каунас і м. Клайпеда. Навчання триває три роки. Студенти навчаються 1 раз на тиждень (у вихідні дні) з питань теорії військової справи, а також отримують практичні навички під час проведення польових вправ, які тривають, у середньому, два тижні щороку під час літніх канікул.

Під час навчання студентам, які проходять військову підготовку, надається військовий одяг і боєприпаси, виплачується грошова компенсація на харчування (5,4 євро в день або вони забезпечуються харчуванням) i 
фіксована сума коштів на особисті нужди. У разі, якщо студенти навчаються за спеціальностями: льотна експлуатація літаків (вертольотів), управління польотами літаків, авіаційне машинобудування, електроніка, судоводіння, експлуатація суднового енергетичного обладнання, то вони отримують додаткову фінансову підтримку для навчання.

На навчання за програмами військової підготовки приймаються як хлопці, так і для дівчата, які відповідають наступним вимогам: є студентами ВНЗ віком від 18 до 32 років включно, які не вчинили умисних злочинів та придатні для проходження військової служби за медичними показниками.

Основні навчальні заняття за програмами підготовки молодших офіцерів (резерва) проводяться: у м. Вільнюс - Військова академія Литви генерала Йонаса Жемайтіса; у м. Каунас - Школа підготовки сержантів імені дивізійного генерала Стасіса Раштікіса; у м. Клайпеда - Драгунський механізований батальйон литовського великого князя Бутейджідіса.

Навчальна програма у перший рік військової підготовки розрахована на набуття знань, практичних навичок та компетенцій необхідних для виконання посадових обов'язків професійного солдата, на другий рік військової підготовки - набуття знань, практичних навичок та компетенцій необхідних для виконання посадових обов'язків командира відділення (сержанта) та їм рівні, а на третій рік - командира взводу (молодшого офіцера) та їм рівні.

Під час навчання основа увага приділяється наступним питанням: тактика; військові статути та основи військового законодавства; надання першої медичної допомоги; застосування зброї та використання військової техніки; військова топографія; фізичне виховання; військова психологія і педагогіка; лідерство; робота в команді та керувати нею; організація зв'язку, історія військового мистецтва та інші військові дисципліни. Після завершення військової підготовки, проходження табірного збору, успішного складання іспиту, позитивної атестації, складання військової присяги випускнику ВНЗ присвоюється первинне офіцерське звання молодшого лейтенанта. Офіцер має можливість проходити військову службу в резерві або вступити на контрактну військову службу кадрового офіцера.

Висновки: Існуюча СВО Литви успішно пройшла період трансформації збройних сил до вимог НАТО, використовує досвід підготовки військових фахівців у розвинутих країнах-членах альянсу з урахуванням особливостей національної системи освіти. Вона забезпечує підготовку офіцерських кадрів за необхідними військовими спеціальностями. Підготовка офіцерських кадрів здійснюється у єдиному військовому навчальному закладі - Військовій академії імені генерала Йонаса Жемайтіса, яка самостійно проводить підготовку офіцерів тактичного рівня для сухопутних військ, а також сумісно з Вільнюським технічним університетом - офіцерів ВПС, а з Вищою школою морських наук м. Клайпеда - офіцерів ВМС. Підготовка офіцерів оперативного та стратегічного рівнів здійснюється на відповідних курсах у військової академії, а також у Балтійському військовому коледжі. 


\section{ЛІТЕРАТУРА}

1. Черних Ю.О. Аналіз процесу трансформації системи підготовки військових фахівців у військових навчальних закладах збройних сил республіки Литва/ Черних Ю.О., Черних .О.Б.- Збірник наукових праць Військового інституту Київського національного університету імені Тараса Шевченка - К.: ВІКНУ, вип. № 61, 2018, у друці.

2. Конституція Литовської Республіки.- [Електронний ресурс].- Режим доступу: http://www3.lrs.lt/home/Konstitucija/Konstitucija_RU.htm.

3. Lietuvos respublikos mokslo ir studiju istatymas.- [Електронний ресурс].- Режим доступу: https://e-seimas.lrs.lt/portal/legalAct/lt/TAD/TAIS.343430.

4. Lietuvos Respublikos krašto apsaugos sistemos organizavimo ir karo tarnybos istatymas.- [Електронний pecypc].- Режим доступу:https://www.etar.lt/portal/lt/legalActEditions/TAR.15C705E93776.

5. Nutarimas dèl generolo jono žemaičio lietuvos karo akademijos statuto patvirtinimo. [Електронний pecypc].- Режим доступу: https:/leseimas.Irs.lt/portal/legalAct/lt/TAD/TAIS.85019/DYUqpfFpSZ.

6. Dèl asmenų, pretenduojančiu $\mathfrak{i}$ valstybės finansuojamas pirmosios pakopos ir vientisuju studiju vietas, mokymosi rezultatu minimaliu rodikliu nustatymo.- [Електронний ресурс].Режим доступу: https://www.smm.lt/teisesaktai/-banners/click/.

7. Dèl švietimo ir mokslo ministro $2012 \mathrm{~m}$. rugpjūčio 14 d. isakymo nr. v-1200 dèl valstybès (strateginiu) švietimo stebėsenos rodikliu patvirtinimo pakeitimo.- [Електронний peсурc].- Режим доступу: https://www.smm.lt/teisesaktai/-banners/click/.

8. Guidelines of the Minister of National Defence.- [Електронний ресурс].- Режим доступу: http://kam.lt/en/defence_policy_1053/important_documents/planning_document_guidelines_of_the_minister_of_national_defence_2012-2017.html

9. Krašto apsaugos ministro isakymai military strategy of the Republic of Lithuania.[Електронний pecypc].- Режим доступу: http://kam.lt/en/-defence_policy_1053/important_documents/strategical_documents.html.

10. Krašto apsaugos ministro įsakymai. - İsakymas dèl krašto apsaugos sistemai reikalingu specialybių, igyjamu suteikiant aukštojo mokslo kvalifikaciją kitose lietuvos aukštosiose mokyklose, nustatymo.- [Електронний ресурс].- Режим доступу: http://kam.lt/lt/teisine_informacija_568/teises_aktai_569/teises_aktai_reguliuojantys_generolo_jono_zemaicio_lietuvos _karo_akademijos_veikla.html.

11. Karo akademijoje karinis rengimas derinamas su universitetinèmis studijomis.[Електронний pecypc].- Режим доступу:http://www.lka.lt/lt/apie-mus/naujienos/naujienuarchyvas-2017/karinis-rengimas-derinamas-dmgr.html.

12. Lietuvos karo akademijos absolventai tapo karininkais.- [Електронний ресурс].Режим доступу: http://www.lka.lt/lt/apie-mus/naujienos/naujienu-archyvas-2017/lietuvos-karoakademijos-mugh.html.

\section{REFERENCES}

1. Chernih, Yu.O., Chernih,.O.B. (2018). Analiz protsesu transformatsiyi sistemi pidgotovki viyskovih fahivtsiv u viyskovih navchalnih zakladah zbroynih sil respubliki Litva [Analysis of the process of transformation of the system of officers' training in the military educational establishments of the republic of Lithuania].- Military institute of Taras Shevchenko National University of Kiev, vip. № 61, (in Ukrainian).

2. Konstitutsiya litovskoyi respubliki.- [Constitution of the republic of Lithuania] Available at : http://www3.lrs.lt/home/Konstitucija/Konstitucija_-RU.htm (in Ukrainian).

3. Lietuvos respublikos mokslo ir studiju istatymasю- Available at : https://eseimas.lrs.lt/portal/legalAct/lt/TAD/TAIS.343430 (in Lithuanian).

4. Lietuvos Respublikos krašto apsaugos sistemos organizavimo ir karo tarnybos istatymas.- Available at :https://www.etar.lt/portal/lt/legal-ActEditions/TAR.15C705E93776 (in Lithuanian). 
5. Nutarimas dėl generolo jono žemaičio lietuvos karo akademijos statuto patvirtinimo. Available at : https://eseimas.lrs.lt/portal/legalAct/lt/TAD/-TAIS.85019/DYUqpfFpSZ (in Lithuanian).

6. Dėl asmenų, pretenduojančių $\mathfrak{i}$ valstybès finansuojamas pirmosios pakopos ir vientisuju studijų vietas, mokymosi rezultatu minimalių rodiklių nustatymo.- Available at: https://www.smm.lt/teisesaktai/-banners/click/ (in Lithuanian).

7. Dèl švietimo ir mokslo ministro $2012 \mathrm{~m}$. rugpjūčio 14 d. issakymo nr. v-1200 dèl valstybès (strateginiu) švietimo stebėsenos rodiklių patvirtinimo pakeitimo.- Available at: https://www.smm.lt/teisesaktai/-banners/click/ (in Lithuanian).

8. Guidelines of the Minister of National Defence Available at : http://kam.lt/en/defence_policy_1053/important_documents/planning_document_guidelines_of_t he_minister_of_national_defence_2012-2017.html (in Lithuanian).

9. Krašto apsaugos ministro isakymai military strategy of the Republic of Lithuania.Available at : http://kam.lt/en/-defence_policy_1053/important_documents/strategical_documents.html. (in Lithuanian).

10. Krašto apsaugos ministro įsakymai. - İsakymas dėl krašto apsaugos sistemai reikalingu specialybių, igyjamų suteikiant aukštojo mokslo kvalifikaciją kitose lietuvos aukštosiose mokyklose, nustatymo.- Available at : http://kam.lt/lt/teisine_informacija_568/teises_aktai_569/teises_aktai_reguliuojantys_generolo_jono_zemaicio_lietuvos_karo_akademijos_veikla.html (in Lithuanian).

11. Karo akademijoje karinis rengimas derinamas su universitetinemis studijomis.Available at : http://www.lka.lt/lt/apie-mus/naujienos/naujienu-archyvas-2017/karinis-rengimasderinamas-dmgr.html (in Lithuanian).

12. Lietuvos karo akademijos absolventai tapo karininkais.- Available at : http://www.lka.lt/lt/apie-mus/naujienos/naujienu-archyvas-2017/lietuvoskaroakade-mijos-mugh.html (in Lithuanian).

\section{PЕЗЮME} \\ Сергій Богунов, \\ кандидат технических наук, \\ Ольга Черных, \\ Национальный университет обороны Украины \\ имени Ивана Черняховского \\ Юрий Черных, \\ кандидат технических наук, доцент \\ Военный институт Киевского национального университета \\ имени Тараса Шевченко
}

\title{
Организация подготовки офицеров для вооруженных сил республики Литва
}

В статье рассмотрен опыт подготовки офищеров для вооруженных сил республики Литва. Проанализирована модель построения карьеры офичера, начиная с присвоения ему первичного офицерского звания до присвоения воинского звания высшего офицерского состава. Приведень сведения о существующей сети военных учебных заведений для подготовки офицеров тактического, оперативного и стратегического уровней военного управления сухопутных войск, военно-воздушных сил и военно-морских сил. Приведены требования для поступающих в военные учебные заведения различных ступеней подготовки. Указаннь варианть организачии подготовки офицеров на первичные должности. Проведен анализ содержания подготовки офичерских кадров для различных видов вооруженных сил и соответствующих уровней военного управления.

Ключевые слова: система военного образования; вооруженные сильл Литвы; сеть военных учебных заведений; опыт подготовки. 


\section{SUMMARY \\ Serhii Bohunov, \\ $\mathrm{PhD}$ (technical sciences), \\ Olga Chernykh, \\ National Defense University of Ukraine named after Ivan Cherniakhovskyi \\ Yuri Chernykh, \\ $\mathrm{PhD}$ (technical sciences), Associate Professor, Military institute of Taras Shevchenko National University of Kiev}

\section{Organisation of officer training for the armed forces of the republic of Lithuania}

Introduction. Analysis of the foreign experience of the organisation and reformation of the armed forces in other countries, with the respective systems of military education being an integral part, reveals the specific national aspect of such activities in each country. In the meantime, there are some general methodological approaches used in military pedagogic practice across different countries of the world to be practicably considered and applied.

Purpose. To carry out the analysis of the current state of the military education system of the republic of Lithuania for integrating the experience of officer training in the course of further reformation of the national military education system.

Methods. The system of the general scientific methods of theoretical and empirical research, in particular, the theoretical-methodological analysis of the problem and the relevant scholarly resources, systematization and generalization of the scientific information pertaining to the essence and content of the set objectives, monitoring of the existing system of military specialists training in the Armed Forces of the republic of Lithuania, scientific generalisation, the general scientific methods of logical and comparative analysis, systems approach, peer review, analysis and interpretation of the obtained theoretical and empirical data.

Results. The experience of officer training for the Armed Forces of the republic of Lithuania was considered. The options to provide training of officers for the primary positions as well as the "trajectories" of the latter's enrolment were outlined. The process of officer training for different armed services was analyzed. The information about the existing network of the military education institutions providing training for the tactical and operational-tactical grade officers for the Army Military Command, the Air Forces, and the Navy was represented. The terms and officer training trades on the tactical and operational levels were specified.

Originality. The article was the first to comprehensively analyse the transformation of the officer training system for the armed forces of Lithuania to the current models of military specialists training adopted in NATO member states.

Conclusion. The existing military education system in Lithuania has successfully underwent the period of transformation of the armed forces towards meeting NATO standards, building on the experience of military specialists training in the developed member states of the alliance and considering the peculiarities of the national educational system. It provides officer training in the required military trades in the unique military education institution The General Jonas Žemaitis Military Academy of Lithuania, which autonomously provides tactical grade officers training for the Land Force, also training Air Force officers jointly with Vilnius Gediminas Technical University and navy officers in collaboration with Clapeida Graduate School of Marine Sciences (Klaipeda). The training of operative and strategic grade officers is provided on the respective courses at the Military Academy as well as the Baltic Military College.

Key words. Military education system; the armed forces of Lithuania; officer training experience. 